\title{
THE BERKHEISER CASE AND LESSORS' ASSIGNMENT
}

Andrew R. Thompson, LL.B., LL.M., Associate Professor, Faculty of Law, University of Alberta, Co-author (with David E. Lewis), Canadian Oil and Gas, 1957, Butterworth.

\section{The Berkheiser Case}

The Berkheiser case ${ }^{1}$ provides an authorative beginning for examination of problems concerning oil and gas leases. Not the least of these problems is the effect to be given the various types of assignments by a lessor of his royalty and mineral interests.

A brief statement of the facts and result of the case will serve to place it in proper perspective. After making a will in which she devised certain land to her son, a testatrix then made an "unless"2 type of oil and gas lease of the land. The lease was in effect at the time of her death but terminated by surrender soon thereafter. The executors of her estate applied for directions as to the disposition to be made of the oil and gas and of delay rentals accruing and paid after her death. For the estate it was contended that the making of the lease operated to adeem the devise to the son to the extent of oil and gas. The court held that the lease did not have this effect and that the son was entitled as devisee to oil and gas and delay rentals.

In reaching this decision the court classified the oil and gas lease as a profit a prendre." Professor Summers warns against indiscriminate classification of interests in oil and gas since classifications will be valid only to the extent that accurate analogies can be drawn between the physical and economic facts of oil and gas and the facts of substances of known legal status. ${ }^{4}$ In view of this warning, it should be observed that Canadian courts have approached the classification of oil and gas interests with great caution. The identification of the oil and gas lease as a profit a prendre is the culmination of early Ontario cases settling the question for that province and of later cases from the western provinces in which judicial opinion has leaned towards this view. ${ }^{3}$ Even with this weight of judicial opinion Mr. Justice Rand was not content to classify the lease as a profit a prendre without a careful assessment of the physical facts of oil and gas and of the purposes for which the lease was designed. ${ }^{\circ}$ Of the accepted property concepts, Canadian judicial opinion has

\footnotetext{
1[1957] S.C.R. 387, 7 D.L.R. (2d) 721.

'Rand J., at p. 392; Kellock J., at p. 399.

1 Summers Oil and Gas, Vol. 1. \$11, at p. 19.

'Canedian Oil and Gas, \$41.

[1957] S.C.R. 387, at pp. 391, 392.
}

'The feature which identifies an "unless' type of lease is a proviso that if the drilling of a well is not commenced within one year the lease shall terminate unless on or before the anniversary date the lessce shall have paid to the lessor a sum of money for the privilege of deferring drilling for a period of one year, and so on from year to year during the primary term (which is usually 10 years). For a typical "unless" type of lease see Canadian Oil and Gas, Form A.I. (d). For the automatic termination feature of the "unless" type of lease see Canadian Oil and Gas, \$104(1). 
found the profit a prendre the closest analogy to the interests manifestly intended to be created by the parties to the instrument.

Professor Summer's warning must yet be heeded. It is a tendency of the legal mind to treat legal categories as if they were the factors of an electronic computer. Thus, if the proper categories are selected and fed into the machine known as "Law", the correct answer to a problem will automatically result. This type of thinking is not of the high order of judicial thought which produced the Berkheiser decision, nor will it reflect the spirit of that decision if in consequence indiscriminate use of categories is substituted for careful analysis in the solution of oil and gas problems. ${ }^{7}$ There will be a temptation to be less discriminating now that the Berkheiser case has provided a label for identifying the lease and attributing its characteristics. ${ }^{8}$ The courts must resist this temptation; and must be astute to project the analogy which results in the oil and gas lease being identified as a profit a prendre only so far as the essential quality of similarity in physical and economic facts pertains.

\section{The Lessor's Interests}

The ratio of the Berkheiser case is that the lessor of oil and gas under the "unless" type of lease has a reversionary interest in oil and gas expectant upon termination of the lease. In paraphrase of the words of Martin B. in Martyn v. Williams, the nature of this reversionary interest may be stated as follows:

On termination of the lease the lessor is entitled to exercise all the acts which the lease authorized the lessee to do, not by reason of the lessee's estate reverting and continuing as an existing estate, but by virtue of the lessor's ownership of and dominion over his own land. During the continuance of the lease there is the relation of reversioner and ownership of patticular estates between the lessor and the lessee. There is exactly the same privity of estate as exists between seversionet and tenant properly so-called, and upon termination of the oil and gas lease the entire interest in oil and gas reverts to the lessor as upon expiration of an ordinary lease.

In addition to his reversionary interest in oil and gas, the lessor is entitled to benefits under the lease, the royalty on production being the most significant. These lessor's interests have been the subject of widespread speculative dealings in western Canada and particularly in Saskatchewan, where private ownership of mineral interests predominates over government ownership. The legal effect of these dealings will be examined, and for this purpose a typical transaction will be described.

A person wishing to acquire an interest in oil and gas in lands which

TAn example of indiscriminate use of categories is to be found in the judgments of the cours below in the Berkheiser case where the statement of Lord Cairns in Gosron v. Christie (1873), L.R. 2 Sc. and Div. App. 273, at P. 284, that a mineral lease was "a sale out and out of a portion of land" was applied incorrectly to classify the oil and gas lease as an agreement for the sale of land.

8The tendency is notable in Falcon Exploration Ltd. v. Gunderson (1958), 25 W.W.R. 416. The fact that the defendant dealt with the belief that an oil and gas "lease" was an ordinary lease did not by itself support a finding of no agreement to "lease". Want of consensus ad idem is not established merely because the parties are unfamiliar with the legal categories by which their dealings are identified. If the defendant was awase of the usual provisions of an oil and gas "lease" it was immaterial that he did not know that the "Iease" is really a profit a prendre and that the "annual rental" is not a rental at all. The decision is unobjectionable insofar as based on uncertainty.

o(1857), 1 H. * N. 817, 156 E.R. 1430. 
are subject to lease finds ready acceptance to a proposal to acquire a half interest in prospective royalties, and to this end an assignment of an undivided one-half interest in the benefits accruing to the lessor under the lease will be executed by the lessor. ${ }^{10}$ In addition the person will seek to induce the lessor to grant an undivided one-half interest in the mines and minerals, and further, to give an option to lease oil and gas upon termination of the existing lease."

\section{Effect of Assignment of Benefits}

(a) Between Lessor and Lessee

The main benefit accruing to the lessor under the lease is the right to receive royalties should production be obtained. As between lessor and assignee, problems concerning royalty assignments arise most frequently from failure to appreciate the characteristics of a royalty. While the nature of a royalty is the subject of a variety of judicial comment, there is yet no statement binding Canadian courts. ${ }^{12}$ In the case where an assignment is not accompanied by a transfer of the lessor's reversionary estate in oil and gas, an Ontario case has decided that the assignee of a royalty merely has contractual rights, and that these rights are limited to recovery of the royalties payable under the lease existing at the time of the assignment. ${ }^{13}$ Consequently, the assignee's right to royalties disappears upon termination of the lease, and this result would seem to follow even though the lease is terminated by voluntary surrender. The decision is obviously correct if the instrument of assignment is construed to operate only upon the royalties to be paid under the existing lease. Therefore, the person intending to acquire an enduring royalty interest is cautioned to employ an assignment which expressly includes royalties under future as well as existing leases. ${ }^{14}$ At the same time, over-emphasis upon the duration of the royalty should not lead the conveyancer to draw an assignment which leaves doubt whether royalties under the existing lease are included. Such was one of the problems resolved in the assignee's favour in Forseth v. Prudential Trust Co. Ltd. ${ }^{15}$

Litigation in the United States concerning royalties has been frequent owing to failure to apply elementary principles of mathematics correctly. ${ }^{10}$ The zealous land agent experiences little difficulty in persuading the farmer that a one-tenth royalty is more generous by $2 \%$ than a one-eighth royalty.

${ }^{10}$ This assignment often expressly excludes delay rentals.

11These documents are described in Prudential Trust Co. Ltd. v. Cugnet (1956), 5 D.L.R. (2d) 1 (S.C.C.) and in the line of cases following this decision, see Canadian Oil and Gas, \$98(3).

${ }^{12 C e n a d i a n ~ O i l ~ a n d ~ G a s, ~ \$ 106 . ~}$

13 Fuller v. Howell, [1942] I D.L.R. 462 (Ont.).

11The pitfalls to which assignments of royalty interests are subject in the United States are described in Second Annual Institute at p. 226. The article, entitled Mineral Deeds and Royalty Transfers, is by Robert M. Turpin.

15(1956), 20 W.W.R. 282 (Sask.). The problem is dealt with in Seventh Annual Institute at p. 317. The article, entitled Minteral and Royalty Grants and Reservations, is by Robert J. Stanton.

"Serenth Annual Institute at p. 324. The article, entitled Mineral and Royalty Grants and Reservations, is by Robert J. Stanton. 
Persons dealing with the lessor's $121 / 2 \%$ royalty interest readily fail to appreciate that $1 \%$ of that royalty is not a $1 \%$ gross royalty. That such errors have not been the subject of litigation in Canadian courts may be some consolation to those responsible for primary education in this country.

\section{(b) Between Lessee and Assignee}

As between lessee and assignee, the main problem concerns the right of the assignee to be paid delay rentals ${ }^{17}$ and royalties. The assignee desires a title to sue the lessee for royalties independent of the lessor. The lessee desires to avoid the necessity of recognizing assignments and, in particular, objects to dividing the royalty among a number of persons.

With respect to delay rentals, Langlois v. Canadian Superior Oil of California $L t .^{18}$ illustrates the danger attendant upon an assignment from the lessee's point of view. Having been notified of and recognized an assignment by the lessor of his interest, the lessee oil company was held bound to pay the next delay rental to the assignee, and failure to do so by the anniversary date resulted in automatic termination of the lease. It mattered not that the company had paid the disputed rental to the lessor. Obviously, the lessee's right hand must know what its left hand is doing. In the case of a large company it will require a well-oiled machinery to enable the paying department to alter its records of delay rental payments the moment the land department receives notice of an assignment it is bound to accept.

Because an assignment of royalties is an assignment of a chose in action, the right of the assignee to sue depends upon the applicable statutory law. In Alberta, if the whole of the lessor's royalty is assigned unconditionally and not by way of charge, and if the assignment is in writing and notified to the lessee, s. 34(15) of the Judicature Act ${ }^{19}$ gives the assignee the right to sue and give a discharge, and he alone can safely be paid the royalty. If the assignment is of a part of the lessor's interest then the assignment is an equitable assignment of a legal chose in action, and it appears that the lessor is a necessary party to any action by the assignee to recover the royalty, either as plaintiff if he willingly lends his name, or as defendant, if he is unwilling. ${ }^{20}$ The lessee may pay the lessor and obtain a legal discharge, but if he does so after notice of the assignment, he runs the risk of being condemned in equity to pay again if the lessor does not account to the assignee."

In Saskatchewan an assignment in writing, whether of the whole or only of a part of the lessor's interest, falls within the purview of s. 2 of the Choses in Action Act. ${ }^{22}$ This section entitles the assignee to sue in his own name without the assistance of the assignor.

17The term "delay rental" denotes the annual payment for the purpose of deferring the commencement of drilling operations provided for in the "unless" type of oil and gas lease. It differs from ordinary rent because the lessee is under no obligation to pay it. If he fails to pay and has not commenced drilling operations, the only legal consequence is loss of the lease, see Canadian Oil and Gas, \$104(1).

${ }^{18}$ (1957), 23 W.W.R. 401 (Man. C.A.)

10R.S.A. 1955, c. 164.

${ }^{20} \mathrm{~A}$ recent auchority is Di Guilo v. Boland, [1958] O.R. 384.

214 Halsbury (3rd ed.), \$1055.

22R.R.S. 1953, c. 360. See Gordon v. Gordon, [1942] 1 W.W.R. 9903 (Sask. CA.). 
The lessee seeks to avoid the burdens of assignment by inserting clauses into the lease preventing partial assignments and naming a depository who will be agent to receive royalties on behalf of the lessor and his assigns. ${ }^{23}$ These clauses harmonize with the royalty trust agreements that are common in cases where royalties are offered for speculation or investment. The royalty is assigned in whole to a trustee who is named depository to receive the royalty and divide it among the persons entitled to participate in the royalty.

(i) Partial Assignments Clause: In the case of an assignment of part of the royalties otherwise than through the medium of a trustee, a difficult question arises concerning the effect of the partial assignment clause on the right to sue of an assignee who has notified his assignment to the lessee. A typical clause of this type will provide that the parties may assign, sub-let or convey provided that no assignment of royalties or other moneys payable under the lease shall be binding upon the lessee unless the same be for the entire interest of the lessor therein. This clause has no couunterpart in United States leases." One American author states that "Oil and gas leases universally provide that the interest of both lessor and lessee is assignable in whole or in part". ${ }^{25}$ It also appears that clauses restricting assignment of choses in action are of rare occurrence generally. The subject-matter is treated in Halsbury in the 3rd edition, where the learned authors summarize the few authorities in a sentence which itself is ambiguous and apparently self-contradictory. The dearch of authority on the point leads onc to probe deeper than merely to assume that the clause against partial assignments binds the assignee because it forms part of the very contract by which the royalty is payable.

If the clause amounts to a covenant by the lessor not to make a partial assignment of royalties then the only consequence of breach will be a liability of the lessor to pay damages. If, on the other hand, the clause is intended to remove the chose in action from the realm of assignability except in the case of assignment of the whole, the question is simply whether the law permits this course to be taken. In this connection it should be noted that the very reason why equity intervened to give recognition to assignments was because assignments were not binding at common law. Should equity withhold its intervention merely because the parties have expressly declared what is in any event the legal effect of their contract, i.e., that it is not assignable? Does such a stipulation amount to more than express dissent to assignment which has been held to be

\footnotetext{
${ }^{23}$ For typical clauses see Canadian Oil and Gas, Div. C. Form A.I (d), clauses 21, 22.

"An examination of Summers, Thornton, the Oil and Gas Reporter and the Annual Institutes has not revealed a single case on such a clause. A related clause to the effeet that no divisions in ownership shall operate to enlarge the obligation or diminish the rights of the lessee is discussed in Second Annisal Institute, p. 245 . The article, entisled

2:Kulp, Oil and Gas Rights, p. 609.

264 Halsbury (3rd ed.), at p. 520.

1076. Condition against assignment. The mere insertion in a contract, as, for example, in a policy of life insurance, of an express condition that it shall not be assignable in any case whatever will not necessarily prevent the assignment of the beneficial interest in the contract, but parties to a contract can by express stipulation render the benefit of the contract incapable of being assigned.
} 
inconsequential if the circumstances are otherwise present for the intervention of equity to enforce the assignment? ? $^{27}$

In the case of McKillop and Benjafield v. Alexander ${ }^{28}$ an agreement for sale of railway lands in Saskatchewan read, in part, as follows:

"No assignment of this contract shall be valid unless the same shall be for the entire interest of the purchasers, and approved and countersigned on behalf of the company."

In this case the majority of the court held that an assignee who had not obtained the approval of the company nevertheless had an equitable interest in the lands. The case involved a conflict between competing assignees, however, and the enforcement of the assignment against the company was not directly in issue. Therefore its authority is weakened for the proposition that the clause against partial assignments is ineffective to relieve the oil and gas lessee of the necessity of recognizing partial assignments. ${ }^{\text {"na }}$

The Land Titles Act of Alberta ${ }^{20}$ contains a section which is not to be found in the statute law of the other western provinces. This section reads as follows:

(1) Any contract in writing for the sale and purchase of any land, mortgage or encumbrance is assignable nothwithstanding anything to the contrary therein contained, and any assignment of any such oontract operates according to its terms to transfer to the assignee therein mentioned all the right, title and interest of the assignor both at law and in equity, subject to the conditions and stipulations contained in the assignment.

(2) Nothing herein contained shall be deemed to affect any rights at law or in equity of the original vendor or owner of the land, mortgage or encumbrance, until notice in writing of the assignment has been either sent to him by registered mail or served upon him in the way process is usually setved, and the notice mentioned in s. 141 shall be deemed to be such notice.

(Italics Supplied)

That the words "contract in writing for the sale and purchase of land ..." might be construed to include an oil and gas lease is indicated by McCollFrontenac Oil Co. Lid. v. Hamilton." It would follow that an assignment by the lessor of his rights under the lease would bind the lessee despite a clause against assignments. It must be cautioned, however, that s. 157 does not mention partial assignments and that the legislature seems to have had only purchasers' assignments in mind.

In Saskatchewan, where the assignment of a part of the royalties falls within s. 2 of the Chose in Action Act, ${ }^{31}$ certain words in the section give express effect to stipulations in contracts against assignment. This section, with the words in question italicized, reads as follows:

S. 2 Every debt and every chose in action arising out of contract shall be assignable by any form of writing containing apt words in that behalf, but subject to conditions and restrictions with respect to the right of transfer as may appertain the original debt or as may be connected with or be contained in the original contract and the assignee thereof may bring an action thereon in his own name as the party might to whom the debt was originally owing or to whom the right of action originally accrued, or he may proceed in respect of the same as though this Act had not been passed.

274 Halsbury (3rd ed.), \$1027.

$28(1912), 45$ S.C.R. 551.

28aThe case is distinguished in McAroy v. Royal Bank of Canada, [1933] 3 W.W.R. 443, where the Saskatchewan Court of Appeal upheld the validity of a similat clause.

20R.S.A. 1955, c. 170, s. 157.

30[1953] 1 S.C.R. 127, [1953] I D.L.R. 721.

S1R.S.S. 1953, c. 360. 
It is suggested, however, that these words may have been intended to preserve only such conditions and restrictions on transfer as pertain generally in law and equity. Like its counterparts, the English Act ${ }^{32}$ and s. $36(\mathrm{~m})$ of the Alberta Judicature $\mathrm{Act}^{33}$ this Saskatchewan legislation was probably intended merely to simplify procedure and not to affect substantive law. ${ }^{34}$ It differs from its counterparts in that it carries the procedural simplifications further, giving the assignee the right to sue in all cases whether the assignment be of the whole or only of part of the debt.

This review of the authorities cannot but leave some doubr as to the effectiveness of a clause restricting the right of the lessor to assign his royalties, and suggests that a lessee who ignores notice of an assignment, even of a part of the royalties, may be condemned by equity to pay the royalties twice despite the inclusion of such a clause in the lease.

(ii) The Depository Clause: This clause may take a variety of forms and probably will expressly bind the assignee of a part of the royalties to accept payment through the medium of the depository. The lessee will then be relieved of the necessity of splitting payments. If the partial assignments clause does not entitle the lessee to ignore a partial assignment then in the case of some depository clauses it is probable that the assignee can require the appointment of a separate depository to receive his share of the royalties. Whether or not the depository will be required to recognize an assignee of a part of the royalties will depend upon the agreement made between the lessor and the depository.

\section{Effect of Assignment of Reversionary Estate}

The foregoing analysis assumes that the transaction between lessor and assignee has been a bare assignment of the benefits under the lease with the reversionary estate in oil and gas remaining in the lessor. It has been mentioned, however, that a typical transaction between lessor and assignee includes, in addition to an assignment of a fractional interest in royalties, an assignment of an undivided interest in mines and minerals. This latter assignment has effect with respect to Torrens system land as an implied agreement to transfer an undivided one-half interest in the lessor's mines and minerals including his reversionary estate in oil and gas. Assuming that the circumstances are such that the implied agreement to transfer this interest is specifically enforceable then notification to the lessee of the assignment duly authenticated must be treated as creating privity of estate between the assignee and the lessee. The effect of privity of estate upon delay rentals and royalties requires a consideration of statutes and cases of some antiquity. It is a matter of great consternation to some and of perverse delight to others to find how often oil and gas problems require a re-examination of basic concepts of law. Those to whom the research of legal obscurities is a pursuit of joy must take care that they do not earn the censure of Mr. Justice Holmes, who found it "- revolting to have no better reason for a

s2Law of Property•Act, 1925, s. 136.

38R.S.A. 1955, c. 164.

36This is the acepted view, see Cheshire and Fifoot, Law of Contrast, 4th ed., p. 417. 
rule of law than that so it was laid down in the time of Henry IV", and "still more revolting if the grounds upon which it was laid down have vanished long since, and the rule persists from blind imitation of the past".

\section{(a) Delay Rents and Royalties as Incident to the Reversion}

(i) As Rent - In Halsbury it is stated that-

"Rents and royalties are true rents in the sense that they are incident to the reversion ..."3as

In this passage the authors of Halsbury are referring to royalties reserved on a lease of mines and minerals. However, the oil and gas lease is not a lease but a profit a prendre, which is an incorporeal hereditament. A number of other passages in Halsbury make it clear that payments reserved out of an incorporeal hereditament are not a true rent and cannot be distrained for, ${ }^{33}$ and this view is the opinion of Chief Justice Williams in Langlois v. Canadian Superior Oil of California Ltd. ${ }^{3 \times}$ Therefore, rents and royalties payable under an oil and gas lease are not incident to the reversion as rent, though the right to receive them may pass with the reversion to the assignee.

(ii) As a Covenant to Pay - The right to receive royalties may pass to the assignee if the covenant to pay them is one running with the reversion. The origin of the right to sue on a covenant because of privity of estate is the statute 32 Henry VIII, c. $34,{ }^{39}$ which was enacted to ensure to the Crown the fruits of confiscation of the ecclesiastical estates. This statute attaches to the land the benefits and burdens of covenants contained in grants of land so as to bind grantees of particular estates and grantees of reversionary estates despite want of privity of contract.

In Saskatchewan the provisions of 32 Henry VIII, c. 34 are to be found in ss. 3-6 of the Landlord and Tenant Act ${ }^{30}$ with a difference that is significant with respect to oil and gas leases. Whereas 32 Henry VIII, c. 34 is expressly made applicable to grants of incorporeal hereditaments, the language of ss. 3-6, with the exception of s. 5,"11 contemplates only the landlord and tenant relationship. Because the oil and gas lease is not a lease, it follows that the Landlord and Tenant Act does not give to the assignee of the reversion in oil and gas the benefit of covenants contained in the lease. However, in Saskatchewan, to the extent that the Landlord and Tenant Act has not replaced it, and in Alberta, where there is no landlord and tenant legislation of like effect, the statute 32 Henry VIII, c. 34 may be applied to attach the benefit of covenants in an oil and gas lease to the reversion if the statute was introduced into these provinces

3:The Path of The Law (1897), 10. Harv. L. R. 457, at p. 469.

3022 Halsbury (2nd ed.), $\$ 1313$.

si12 Halsbury (3rd ed.), \$132; 20 Halsbury (2nd ed.), \$171; 22 Halsbury (2nd ed.), \$1330.

38(1957), 23 W.W.R. 401 (Man.). Chief Justice Williams is the author of Canadian Lay of Landlord and Tenant.

39See Statutes at Large, 1461.1601, at p. 294.

10R.S.S. 1953, c. 312.

"Section $S_{1}$ in attaching to assignees of the reversion the burden of covenants, contains words extending the property interests affected to include "lands, tenements, rents or any other hereditaments". 
as the law of England at July 15, 1870." In the Berkheiser case both Mr. Justice Rand and Mr. Justice Kellock cited Martyn v. William ${ }^{43}$ which decided that a grant of the right "to dig, work and search for china clay, and to raise, get and dispose of the same" was a grant of an incorporeal hereditament, the covenants relating to which ran with the land in favour of assignee of the reversion. Mr. Justice Rand referred to Lord Hastings v. North Eastern Rly. $\mathrm{Co}^{4}{ }^{4}$ as deciding that a covenant to pay for the privilege of a way-leave on which to make and use a railway based on a rate on the coal carried to a certain port ran with the reversion. These cases were applied to hold that the delay rentals in question in the Berkheiser case passed with the reversionary interest in oil and gas under the devise of the land. But the court was not called upon to consider whether $32 \mathrm{Henry} V I I I$, c. 34 had been introduced as the law of Saskatchewan. The question to be asked is whether 32 Henry VIII, c. 34 was reasonably applicable to local conditions prevailing in the NorthWest Territories at July 15,1870 . While the preamble to the statute identifies its purpose as one of securing the Crown the profits from the confiscated ecclesiastical estates, the statute is expressly extended to the benefit of all grantees of reversions, and in this broader sense may be said to be applicable to local conditions in the North West Territories at July 15, 1870. This matter is not free from doubt, however, as an examination of the decided cases will reveal. ${ }^{45}$ In the United States the prevailing view is that royalties run with the reversionary estate in oil and gas."

\section{(b) Effect Between Assignor and Assignee}

In Alberta the Transfer and Descent of Land $A \mathrm{Ct}^{17}$ provides that the effect of a transfer or conveyance is to pass all the estate or interest of the transferor or grantor in the land except such estate or interest as might be specifically reserved or excepted in the instrument. Of the same effect is s. 84 of the Land Titles Act of Saskatchewan. " Therefore, where an owner in fee simple makes an oil and gas lease and then assigns or transfers his estate in the land, the assignee or transferee obtains the reversionary estate in oil and gas unless these substances specifically or mines and minerals generally are excepted. The covenant to pay royalties passes with the reversionary estate to the assignee or transferee." In fact, upon notice to the lessee of the assign-

\footnotetext{
12The legislative provisions for the adoption of the laws of England at July 15, 1870 into the North.West Territories are reviewed in the julgment of Harvey C.J.A. in Re Simpson, [1927] 3 W.W.R. 534, [1927] 4 D.L.R. 817.

$13(1857)$, I H. \& N. 817, 156 E.R. 1430.

$41[1898] 2$ Ch. 674.

4iRe Simpson, [1927] 3 W.W.R. 534, [1927] 4 D.L.R. 817 (Alta. C.A.) followed in Re Budd Estate (1958), 24 W.W.R. 383 (Alta.) (rule in Shelley's Case held inapplicable); Huggard Assets Lid. v. A.G. for Alberta, [1953] A.C. 420, 8. W.W.R. (N.S.) S61, [1953] 3 D.L.R. 225 (P.C. Alta.) (Starute of Tenures, 1660, probably not applieable); $R_{e}$ Moffat Estate (1955), 16 W.W.R. 314 (Sask.) (Sented Estates Act, 1856 (Imp.) c. 120, s. 17 held applicable).
}

'Summers Oil and Gas, \$600.

1TR.S.A. 1955, c. 342, s. $8(1)$.

18R.S.S. 1953 , c. 108.

10 See p. 256 , ante. 
ment or transfer, the lessee cannot safely pay delay tentals to anyone but the assignee or transferee. ${ }^{30}$

In the case of an assignment of an undivided half interest in mines and minerals, the assignor and assignee become tenants in common of the reversionary estate in oil and gas. In the event this estate is severed, as by partition, the apportionment of delay rentals and royalties must be considered. In $\operatorname{Re}$ Dawson and Bellis the Ontario Court of Appeal held that where three tenants in common severed their interests in land leased for oil and gas the royalties were to be apportioned according to the proportions which the divided parts bore to the whole of the land, notwithstanding that the gas wells on which the royalties were paid were located entirely on one of the parts. To reach this conclusion the court treated the royalties as in essence a rent and incident to the land. The opposite result has generally prevailed in the United States where the non-apportionment rule is applied in all oil-producing states except Pennsylvania. The non-apportionment rule is considered by many to lead to hardships and difficult problems of application. ${ }^{53}$ The Ontario decision provides the opportunity for Canadian courts to avoid these hardships and difficulties.

\section{(c) Effect Between Assignee and Lessee}

An assignment of the lessor's reversionary interest in oil and gas creates privity of estate between the lessee and the assignee, the relation being that of tenant of a particular estate and tenant of the reversionary estate. ${ }^{\text {st }}$ When the lessee is notified of the assignment the royalties must be paid to the assignee because, like rent, they run with the reversion. ${ }^{\text {sS }}$ In Langlois v. Canadian Superior Oil of California Ltd. ${ }^{\mathrm{B}}$ it was held that the assignee was the only person lawfully entitled to be paid delay rentals. In that case the lease gave the right to assign and assignments both of the delay rentals and royalties and of the reversionary estate had been duly made and notified. The failure of the lessee to pay delay rental to the assignee resulted in automatic termination of the lease. Probably the assignment of reversionary estate alone would have entitled the assignee to receive the delay rentals as payments which, like royalties, run with the reversion. ${ }^{\text {st }}$

(i) The Partial Assignments Clause-The clause against assignment of less than the lessor's entire interest in royalties and other payments under the

ooLanglois v. Canadian Superior Oil of California Lid. (1957), 23 W.W.R. 401; see p. 252, ante.

S1 [1945] O.R. 825.

"Eighth Annual Institute, p. 125. The article, entitled Separately Ooned Tracts Under Single Leases, is by Claude O'Quin.

s3ibid.

st Attornment is unnecessary; in Alberta, assuming (1705) 4 \& 5 Anne, c. 3, ss. 9, 10 (am. (1737) 11 Geo. 2, c. 19, s. 11) to be applicable English law at July 15, 1870; in Saskatchewan, by the Landlord and Tenant Act, R.S.S. 1953, c. 312, s. 58.

DSSee p. 256 ante.

${ }^{80}$ (1957), 23 W.W.R. 401.

57 A case might be made for distinguishing delay rentals from royalties in this respect. While royalties are akin to rent, delay rentals are treated more as option money, payments of which extend the term from year to year. Option payments must be made strictly in accordance with the tetms of the contract and hence it might be held that, despite an assignment of the reversionary estate, delay rentals must be paid to the lessor named in the lease. 
lease has been discussed in connection with a partial assignment of benefits. "i The effect of the clause must now be considered in the case of a partial assignment of the reversionary estate. Apart from the clause, if the reversionary estate is divided and the royalties are apportioned, the obligation to pay them is itself divided, requiring the lessee to pay the assignee his portion. ${ }^{\text {so }}$ If the partial assignment is of undivided interests then the assignor and assignee are tenants in common of the reversionary estate and, apart from the clause, the assignee can probably require the lessee by notice to pay the royalties in several portions according to the fractional interests of each. ${ }^{\circ 0}$ In either case the lessee will find himself obliged to divide royalty payments. The very object of the partial assignment clause is to excuse the lessee from this obligation, and the question is whether the clause effectively achieves this object. Doubt has been raised as to the effectiveness of the clause in the case of partial assignments of benefits." . Of even more doubtful effect is the attempt to apply the clause in the case of partial assignments of the reversionary estate. The main difficulty is that the clause does not even purport to affect such assignments." In result, the partial assignment of the reversionary estate binds the lessee when it is notified to him, and as a legal consequence the right to royalties runs with the several reversionary estates and the obligation of the lessee to pay the royalties may be divided. Should the clause against partial assignments purport to restrict assignment of the reversionary estate the further difficulty arises whether the restriction is a valid restraint on alienation. ${ }^{0.3}$

(ii) The Depository Clause-If the lessee is bound by a partial assignment of the reversionary estate in oil and gas it may be that the depository clause will not enable him to avoid the necessity of dividing royalty payments and paying portions to the several assignees of the reversionary estate. This result may follow either because the several assignees may be entitled under the

\footnotetext{
58 see p. 243 ante.

50 This again is the result of 32 Henry VIII, c. 34 . See 20 Halsbury (2nd ed.) $\$ \$ 199,449$.

COThe effect of a notice by one of two tenants in common to the lessee to sever the rent and pay a moiety to each is obscure. In Harrison v. Barnby (1793), 5 Term Rep. 246, 101 E.R. 138, it was held that a terre-tenant (tenant in possession) holding under two tenants in common could not pay the whole tent to one after notice from the other not to pay it, and, if he did, the latter could distrain for his share. This case was applied in Ontario in Bradburne v. Shanly (1859), $7 \mathrm{Gr}$. 569, where it was held that an agent for receiving and paying over rents was liable for the share of rents due a co-tenant where he ignored a notice to pay the rents in several portions and paid the whole of the rents to the other cenant in common. Apparently the effect of the notices in these cases was not a voluntary partition. In a United States case, Carter Oil Co. v. Crude Oil Co., 201 F. (2d) 547, it was held that where a lessee paid royalties to a tenant in common knowing the latter was misappropriating his co-tenant's share, the lessee was liable to pay this share over again to the co-tenant. Partition in oil and gas cases in the United States is discussed in Ninth Annual Institute in an article entitled Partition of Mineral Interests by Charles B. Wallace.

01 see p. 255 ante.

o2Provisions against assignment ordinarily receive strict construction, e.g. Williams, Canadian Low of Landlord and Tenant, 3rd. ed. p. 676. Therefote, the assignment of "royalties and other moneys payable under the lease" will not likely be construed to include an assignment of the reversionary estate.

${ }^{63}$ The restraint is an entire restraint on alienation as to parts of the land and may be invalid, but see McA roy v. Royal Bank of Canada, [1933] 3 W.W.R. 433, at p. 436.
} 
wording of the depository clause to name separate depositories to which the shares of royalties are to be paid or because the depository clause, as a burdensome covenant requiring the lessor to appoint an agent to receive payments, does not touch or concern the land and therefore does not run with the land to be binding upon the assignees. ${ }^{\text {.1 }}$

\section{Option to Lease}

In drafting an option to lease oil and gas upon the termination of an existing lease two problems exist - one of law and one of mechanics. The legal problem concerns the application of the rule against perpetuities since the termination of the existing lease may occur at a remote time. In Forseth v. Prudential Trust Co. Ltd. ${ }^{\text {us }}$ the court refused a declaration that an option to lease on the termination of an existing lease was void as offending the rule, noting that the granting of a declaratory judgment is a discretionary matter and that no attempt had been made to exercise the option. The court pointed out that the authorities lean to the view that as between the parties (as distinct from the grantee and a successor to the grantor) the rule has no application, particularly where enforcement is sought within the limits of the rule. The possible application of the rule may be avoided by limiting the time for exercise of the option to the life of the optionor and twenty-one years thereafter. ${ }^{* 6}$

The problem of mechanics concerns again the time of exercise of the option. With respect to time there must be certainty. But the very circumstances which will result in termination of the existing lease are most uncertain - at least so far as the optionee is concerned, who has not the means of knowing whether delay rentals have been duly paid or whether production is continuing the lease under the "thereafter" clause of the habendum. Langlois v. Canadian Superior Oil of California Ltd. ${ }^{\text {is }}$ shows that a lease may have expired several years before even the parties become aware that errors in the payment of a delay rental have brought into operation the automatic termination clause. To give certainty to the provisions for exercising the option requires all the ingenuity a draftsman can command. It is not sufficient to provide that the option shall be exercisable within a stated period after notice of termination of the existing lease is given to the optionee by the optionor because such notice may not be given. If such a requirement is coupled with an obligation on the optionor's part to give notice then there are still the difficulties that the obligation will not bind an assignee of the

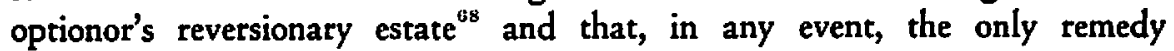
available to the optionee for failure of the optionor to give notice may be damages. While equity will look on that as done which ought to be done, and

o'For covenants which touch or concern the land, see $20 \mathrm{Hd}$ dsbury (2nd ed.), \$\$432, 450.

os (1956) 20 W.W.R. 282, 7 D.L.R. (2d) 44 (Sask.).

corfor application of the rule against perpetuities in related oil and gas problems in the United States, see Eighth Annual Institute, p. 201. The article, entitled Impact of Future Interests on Oil and Gas, is by Dwight A. Olds.

or (1957), 23 W.W.R. 401 (Man. C.A.).

${ }^{68}$ The option, if caveated, will bind the assignee, but not the obligation to give notice of termination. 
therefore, in an action to enforce the option, will treat the matter as if notice had been given by the optionor when he became aware of the circumstances terminating the lease, the probability is that the stated period for exercising the option after notice will have expired in the meantime. In result, the optionee will lose the option unless equity can assume, in addition to notice having been given, that the optionee would have exercised the option within the required time. The second assumption seems unprecedented in equitable jurisdiction, and, in consequence, the optionee is left to his remedy in damages. Even these damages must be of doubtful measure because again the court can act merely on a probability that the optionee would have exercised the option.

If the time for exercise of the option is made to run from the date when the optionee acquires, from whatever source, knowledge of termination of the existing lease, the difficulties noted above are avoided, but the dilemma remains that the optionee may be ignorant of circumstances which automatically terminate the lease and the optionor may simply ignore such circumstances and permit the situation to continue as if the lease were subsisting. The only solution that can be offered, and still a defective one, is a clause combining the above procedures. Such a clause would extend the time for exercise of the option to a stated period after knowledge of termination of the existing lease comes to the optionee, and at the same time would obligate the optionor to give notice to the optionee of termination should it come to his knowledge.

\section{Conclusion}

By no means have all the legal problems arising out of lessor's assignments been considered, but those that have reveal an intricate subject-matter with a dearth of authorities. There is really only the Berkheiser case as a starting point. From that beginning the writer's opinions may be summarized:

(1) An assignment of benefits under an oil and gas lease without an assignment of the reversionary estate in oil and gas operates as an assignment of royalties as choses in action, the rights of the assignee depending wholly on the terms of assignment, the lease and the applicable statute law. Probably assignments of less than the entire interest of the lessor will not bind the lessee where the lease contains a partial assignment clause. Bare royalty assignments can best be accomplished by means of a royalty trust agreement naming a trustee as assignee of the reversionary estate in oil and gas to receive the royalty payments and distribute them among the assignees of the royalty.

(2) An assignment of the reversionary estate in oil and gas creates privity of estate between the assignee and the lessee and carries as incident to the reversion the right to delay tentals and royalties. Where the lessor is surface and mineral owner and intends to dispose of his land while retaining benefits under an existing oil and gas lease, he must except mines and minerals, or at least oil and gas, from his disposition of the land. Despite the partial assignments clause 
the assignunent of divided or undivided parts of the reversionary estate will bind the lessee upon notice and he will ignore the division of royalties at his. peril. This result will work no undue hardship on lessees for the reversionary estate in oil and gas is seldom divided in fractions smaller than a half. The multiple division of royalties can be satisfactorily accomplished only by the royalty trust agreement.

(3) Options to lease upon the termination of the existing lease tax the ingenuity for improvisation of a fully effective formula.

\section{GIFTS OF LAW BOOKS TO UNIVERSITY}

In December 1958 Texaco Exploration Company gave a most generous gift of law books to the University for use in the Faculty of Law. Included are a complete set of Western Weekly Reports, a Canadian Abridgment, English and Empire Digest, Halsbury (2nd and 3rd Editions), C.E.D. (Western) 2nd Ed., vols 1-5, Summers on Oil and Gas and several other books. These books are not only of substantial monetary value but most useful and all are in excellent condition.

C. H. Grant, Q.C. has also made a useful gift of the Canadian Bar Review and of the Proceedings of the Canadian Bar Association.

Within the past two years or so other valuable and useful gifts of books have been received from S. Bruce Smith, Q.C. of Edmonton, Clarence Campbell, Q.C., now of Montreal and President of the National Hockey League, and G. W. R. Reed, formerly Associate Professor of Law here and now ViceChairman of the Ontario Labour Board. 